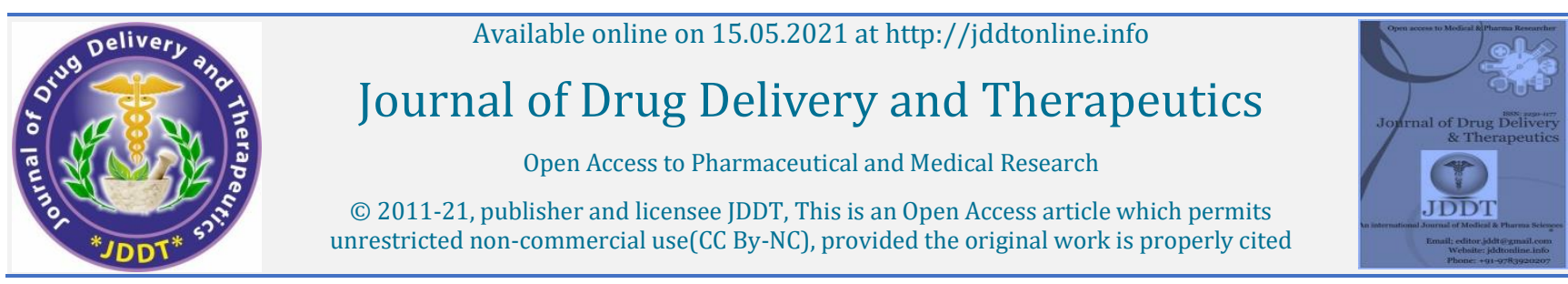

(C) 2011-21, publisher and licensee JDDT, This is an Open Access article which permits

Open Access Full Text Article

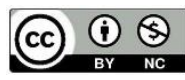

Research Article

\title{
Isolation and Identification of Multiple Drug Resistant Bacterial Pathogens from Well Water Samples in and Around Wolaita Sodo Town, Southern Ethiopia
}

\author{
Krishna Moorthy Sivalingam ${ }^{1 *}$ and Subramaniyan Vaithilingam ${ }^{2}$ \\ ${ }^{*}$ Department of Biology, College of Natural and Computational Sciences, Wolaita Sodo University, Wolaita Sodo, Ethiopia \\ ${ }^{2}$ Post Graduate and Research Department of Biotechnology, JJ College of Arts and Science, Pudukkottai, Tamilnadu, India
}

\begin{tabular}{ll}
\hline Article Info & \\
\hline & Article History: \\
& Received 23 March 2021 \\
& Accepted 04 May 2021 \\
&
\end{tabular}

Cite this article as:

Sivalingam KM, Vaithilingam S, Isolation and Identification of Multiple Drug Resistant Bacterial Pathogens from Well Water Samples in and Around Wolaita Sodo Town, Southern Ethiopia, Journal of Drug Delivery and Therapeutics. 2021; 11(3):70-78

DOI: http://dx.doi.org/10.22270/jddt.v11i3.4794

*Address for Correspondence:

Dr. S. Krishna Moorthy, Associate Professor, Department of Biology, B-062, College of Natural and Computational Sciences, Wolaita Sodo University, Post Box No. 138, Wolaita Sodo, Ethiopia

\begin{abstract}
Water for human consumption is required to be free from any bacteria that might pose a health risk. The worldwide prevalence of pathogen contamination is a serious concern, and enhancing the understanding of major pathogen sources and their significant impacts on water resources is crucial. Further, these organisms underwent multiple drug resistance in their systems. The present study mainly focused on Multiple Drug Resistant (MDR) bacterial pathogens in well water system in and around Wolaita Sodo Town. A total of 380 well water samples were collected and screened for SPC, enrichment process and selective media isolation. Further all the isolates were used to know the sensitivity/resistant patterns by Bauer-Kirby method and based on resistant pattern MDR isolates were assessed and recorded. Amon 380 well water samples screened for water potability by SPC method, 154 samples were positive. Among 154 SPC positive water samples yielded 106 different isolates of bacteria and it includes five genera, namely Escherichia coli, Salmonella spp., Shigella spp., Proteus spp. and Enterococcus spp. All the isolated five genus were confirmed by preliminary characters, colony morphology and biochemical tests. Among 106 isolates, 13 isolates of E. coli, 3 isolates of Salmonella spp., 21 isolates of Shigella spp., 9 isolates of Proteus spp., and 4 isolates of Enterococcus spp. were documented as MDR bacterial pathogens. The high prevalence rate of multiple drug resistant bacterial pathogens in the well water samples could potentially pose a threat to people consuming this water. Therefore, the present study suggesting to monitor the quality of water and strict quality control measures should be put in place to ensure the effective treatment of drinking water.
\end{abstract}

Keywords: Water samples, Standard Plate Count, Antibacterial Susceptibility Test and MDR

\section{INTRODUCTION}

Water is a natural resource and is essential to sustain life. Accessibility and availability of fresh clean water does not only play a crucial role in economic development and social welfare, but also it is essential element in health, food production and poverty reduction. ${ }^{1}$ Water helps to maintain the moisture of internal organs of the body; maintains normal volume and consistency of fluids such as blood and lymph; regulates body temperature; removes poisons or toxins from the body through, urine sweat and breathing; and is essential for regulating the normal structure and function of the skin. ${ }^{2}$ Around 700 million people suffer from lack of access to clean and safe water and 2.2 million people die from water-borne diseases every year globally. Infants are the most vulnerable targets of these diseases. ${ }^{3}$ The problem is even severe in developing countries where generally the drinking water is untreated. Bacteria constitute one of the major contaminants of water and they have been reported to persist even in the extreme environmental conditions and oligotrophic conditions. ${ }^{4}$
Diseases related to contamination of drinking water constitute a major burden on public health. The principal risk to the health is from ingestion of water contaminated with faeces containing pathogens that cause infectious diseases such as cholera and other diarrhoea diseases, dysenteries and enteric fevers. ${ }^{5}$ As a result, water related diseases continue to be one of the major health problems globally. ${ }^{6}$ It is estimated that globally $80 \%$ of all illnesses are linked to use of unsafe and microbiologically poor water quality.7,8 Increase in antibiotic resistance level is now a global problem. Infections with antibiotic resistant bacteria make the therapeutic options for infection treatment, extremely difficult or virtually impossible in some instances. ${ }^{9}$

Antibiotic resistance is not only found in pathogenic bacteria but also in environmental organisms inhabiting terrestrial and aquatic habitats. Higher numbers of resistant bacteria occur in polluted habitats compared with unpolluted habitats, indicating that humans have contributed substantially to the increased proportion of resistant 
bacteria occurring in the environment. Antibiotics exert a selection in favour of resistant bacteria by killing or inhibiting growth of susceptible bacteria; resistant bacteria can adapt to environmental conditions and serve as vectors for the spread of antibiotic resistance. The main risk for public health is that resistance genes are transferred from environmental bacteria to human pathogen. In general terms, the greatest microbial risks are associated with ingestion of water that is contaminated with human or animal faeces. Wastewater discharges in fresh waters and costal seawaters are the major source of faecal microorganisms, including pathogens. Acute microbial diarrheal diseases are a major public health problem in developing countries. People affected by diarrheal diseases are those with the lowest financial resources and poorest hygienic facilities. Children under five, primarily in Asian and African countries, are the most affected by microbial diseases transmitted through water. ${ }^{10}$

Microbial water-borne diseases also affect developed countries. In the USA, it has been estimated that each year 560,000 people suffer from severe water-borne diseases, and 7.1 million suffer from a mild to moderate infections, resulting in estimated 12,000 deaths a year. ${ }^{11}$ In 2015 , reports revealed that around 319 million people in subSaharan African, characterized by the shortage of clean and safe water for drinking. ${ }^{12}$ Antimicrobial agents' resistance has been recognized as an emerging worldwide problem, in both human and veterinary medicine, and drug abuse is considered the most important factor for the emergence, selection and dissemination of antimicrobial agent resistant bacteria. ${ }^{13}$ Therefore, the present study majorly focussed on isolation and identification of Multi Drug Resistant Bacteria from well water samples in and around Wolaita Sodo Town, Southern Ethiopia.

\section{MATERIALS AND METHODS}

\section{Sample source}

The sample source was well water which were collected from in and around Wolaita Sodo Town, SNNPR, Southern Ethiopia.

\section{Sample size determination}

For a risk assessment of bacteriological examination, sample size was calculated by prevalence $35.61 \%$ of total coliform count of bacteria pathogenic from different water sources from Shashemane Town and 0.05 allowable errors and 95\% confidence interval using the formula recommended by Thrusfield. ${ }^{14}$

$$
\mathrm{N}=\frac{\mathrm{Z}^{2} \mathrm{p}(1-\mathrm{p}}{\mathrm{d}^{2}}
$$

Where, $\mathrm{N}=$ required sample size; $\mathrm{P}$ = prevalence; $\mathrm{d}^{2}=$ desired absolute precision

Prevalence which is $35.61 \%$

$\mathrm{q}=$ is failure which is calculated as $1-\mathrm{p}(1-0.3167)=0.65$

$\mathrm{d}$ is allowed error $=0.05$,

Value from the normal distribution for the desired confidence level which is $=1.96$ in this study. Based on 31.6 $\%$ prevalence and $Z$ value of 1.96 the sample size will be;

$$
\mathrm{N}=1.96^{2}(0.35)(0.65) /(0.05)^{2}=349.4
$$

Further to be added $10 \%$ contingency for anticipated non response rate and it gives 35

$$
\mathrm{N}=349+35=384
$$

\section{Sampling technique, sample collection and transporting}

A total of 380 well water samples were collected from 38 different wells available in and around Wolaita Sodo Town. The well water samples were collected ten rounds with every three days interval. All the samples were collected aseptically with sterile water bottles and all samples properly noted. Finally, all the samples were transported to Post Graduate Microbiology Laboratory, Wolaita Sodo University, Wolaita Sodo.

\section{Standard Plate Count (SPC)}

All the samples were tested for presence of bacterial species in ml water sample by SPC method. Each sample of well water $(1 \mathrm{ml})$ were plated in molten nutrient agar by pour plate technique (original and duplicate maintained). Further plates were incubated for $18-24$ hours at $37^{\circ} \mathrm{C}$. Then plates were counted for presence of colonies. The positive result showed by more than $100 \mathrm{cfu} / \mathrm{ml}$ and indicated earliest danger of outbreak of water-borne infection. The SPC method mainly focused water potability. Further all positive samples were subjected to enrichment process for isolation of bacteria. 15

\section{Enrichment of water samples}

All positive well water samples were further inoculated in $100 \mathrm{ml}$ of nutrient broth ( $1 \mathrm{ml}$ positive SPC sample) and enriched for growth of bacteria at $37^{\circ} \mathrm{C}$ for 16 to 24 hours. Further these samples were used for selective isolation.

\section{Selective media isolation}

After completion of enrichment process, from the enrichment broth aseptically the inoculum was transferred to different selective media, such as, Endo agar for Escherichia coli, Hekteon enteric agar medium for Salmonella spp. and Shigella spp, CLED for other members of enterobacteriaceae and Enterococcus spp. by quadrant streaking process

Preliminary tests, colony morphology and biochemical identification of bacteria

From the selective media, the part of each suspected colonies was tested for following tests, grams staining, motility, catalase and oxidase. Further these different isolates isolated from appropriate selective media were inoculated again all the selective media individually. All the results were analysed and recorded in tables.

\section{Maintenance and preservation of pure culture strains}

The organisms grown in appropriate media for 18 hours were preserved in a nutrient agar slant at $2-8^{\circ} \mathrm{C}$ in a refrigerator and the culture was used within two weeks for routine laboratory works. For long term preservation, strains were stored in brain heart infusion broth (BHIB) (HiMedia- LQ210D) with 20\% glycerol and stored frozen without significant loss of viability at $-20^{\circ} \mathrm{C}$ until further study. ${ }^{16}$

\section{Antimicrobial susceptibility testing}

All the clinical isolates were tested for their sensitivity and resistant pattern by disc diffusion method. ${ }^{17}$ The culture plates were prepared by pouring $20 \mathrm{ml}$ of Mueller Hinton agar (MHA) (HiMedia- M173). The depth of the medium was approximately $4 \mathrm{~mm}$. Three to four similar colonies of pure cultures were inoculated with tryptone soy broth (HiMedia$\mathrm{M} 323$ ), further, it was incubated at $37^{\circ} \mathrm{C}$ for 2-8 hours and inoculum size was adjusted to yield uniform suspension containing $10^{5}-10^{6}$ cells $/ \mathrm{ml}$ (McFarland's standard). The agar surface of the plates was swabbed in three directions, 
turning the plates at $60^{\circ}$ between each swabbing. Confluent growth is desirable for accurate results. A total of eight antibiotics were used for disc diffusion test. The antibiotic discs were placed over the surface of swabbed medium with equal distance to avoid the overlapping of the zone of inhibition. Then the discs were pressed gently on the surface of the medium and allowed to stand in refrigerator for 30 minutes (pre-diffusion time). The plates were incubated at $37^{\circ} \mathrm{C}$ for $16-18$ hours during which the activity was evidenced by the presence of zone of inhibition surrounding the discs. Each experiment was done in triplicate.

\section{Criteria for the selection of multi-drug resistant (MDR) strains}

Bacterial isolates resistant to three or more drugs of different structural classes were considered as MDR strains. ${ }^{18}$ In the current study, the drugs belong to the different classes of antibiotics were included and at the maximum eight antibiotics were used against all the isolates of individual genus.

\section{Reference strains}

Escherichia coli (ATCC-25922) and Enterococcus spp. (ATCC29212) were used as a quality control throughout the study for culture and antimicrobial susceptibility testing. All the strains obtained from Ethiopian Public Health Institute, Addis Ababa, Ethiopia.

\section{Data Entry and analysis}

After completion of AST, each measurement of different antibiotics was recorded according to the standard chart, such as, sensitivity, intermediate and resistant. Further the percentage of sensitivity/resistant had been calculated, based on the AST multi drug resistant bacteria (MDR) were assessed and calculated. All the values were recorded in appropriate tables.

\section{RESULTS}

\section{Isolation and identification of bacteria pathogens}

All the collected water samples (380) were used to count the number of colonies using standard plate count. Standard Plate Count (SPC) normally used to know the potability of water samples. Among the 380 water samples, 154 samples were positive (more than $100 \mathrm{cfu} / \mathrm{ml}$ in water sample considered to positive) rest of the samples were negative in SPC method. Total of 106 bacterial pathogens were isolated from all 154 positive SPC samples. All the 106 isolates were further identified based on colony morphology using selective media and different biochemical tests. Table 1 showed the results of preliminary characters of bacterial isolates isolated from various water samples. Among five bacterial isolates, four were gram negative bacteria and one was gram negative bacteria. All the isolates were inoculated in Nutrient agar, MacConkey agar and Selective media of concern bacterial isolates and confirmed as Escherichia coli, Salmonella spp., Shigella spp., Proteus spp., and Enterococcus spp. based on the colony morphological characters (Table1).

Further all the five different genera were confirmed by biochemical tests. Among these five different genera, four genera such as Escherichia coli, Salmonella spp., Shigella spp., and Proteus spp., showed Gram's Negative except Enterococcus spp., which showed Positive in Gram's staining.

Table 1: Identification of bacterial pathogens based on Colony Morphology using MacConkey agar, Nutrient agar and Selective agar media

\begin{tabular}{|l|l|l|}
\hline \multirow{2}{*}{ Bacterial Species } & \multicolumn{2}{|c|}{ Colony Morphology } \\
\cline { 2 - 3 } & \multicolumn{1}{|c|}{ MacConkey Agar } & \multicolumn{1}{c|}{ Selective Agar } \\
\hline Escherichia coli & Lactose fermenting pink coloured colonies & Endo agar: A faint pink colour colonies \\
\hline Salmonella spp. & Non-lactose fermenting colourless colonies & $\begin{array}{l}\text { Hektoen enteric agar: Green colonies with black } \\
\text { centre }\end{array}$ \\
\hline Shigella spp. & Non-lactose fermenting colourless colonies & Hektoen enteric agar: Colourless colonies \\
\hline Proteus spp. & Non-lactose fermenting colourless colonies & CLED Agar: Translucent blue colonies \\
\hline Enterococcus spp. & Nutrient Agar: White, spherical colonies & CLED Agar: Deep yellow colonies and uniform in colour \\
\hline
\end{tabular}

In case of motility test, Escherichia coli, Salmonella spp., and Proteus spp., showed motile and Shigella spp., and Enterococcus spp., showed non-motile. All the five different genera showed oxidase negative and catalase positive except Enterococcus spp., which showed catalase negative (Table2).

Table 2: Identification of bacterial pathogens based on the biochemical tests

\begin{tabular}{|l|l|l|l|l|}
\hline Bacterial species & Gram staining & Motility & Catalase & Oxidase \\
\hline Escherichia coli & Gram negative & Motile & Positive & Negative \\
\hline Salmonella spp. & Gram negative & Motile & Positive & Negative \\
\hline Shigella spp. & Gram negative & Non-motile & Positive & Negative \\
\hline Proteus spp. & Gram negative & Motile & Positive & Negative \\
\hline Enterococcus spp. & Gram positive & Non-motile & Negative & Negative \\
\hline
\end{tabular}


Prevalence of rate of bacterial pathogens isolated from well water samples

Overall prevalence of bacterial isolates was assessed and recorded in table-3. Total number of 106 isolates of five different genera were isolated from 380 samples and therefore the overall prevalence rate was $27.89 \%(106$ isolates). The highest prevalence rate was with Escherichia coli $9.2 \%$ (35 isolates), followed by Shigella spp., Proteus spp., Enterococcus spp., and Salmonella spp. with respective prevalence rate of $8.68 \%, 4.47 \%, 3.15 \%$ and 2.36 .

Table 3: Prevalence rate of bacterial pathogens isolates from well water samples

\begin{tabular}{|c|c|c|c|c|}
\hline S.No. & Name of the isolates & $\begin{array}{c}\text { Total number of well water } \\
\text { samples }\end{array}$ & Number of Isolates & Prevalence rate (\%) \\
\hline 1 & Escherichia coli & \multirow{5}{*}{380} & 35 & 9.21 \\
\hline 2 & Salmonella spp. & & 9 & 2.36 \\
\hline 3 & Shigella spp. & & 33 & 8.68 \\
\hline 4 & Proteus spp. & & 17 & 4.47 \\
\hline 5 & Enterococcus spp. & & 12 & 3.15 \\
\hline 6 & & Total Number of Isolates & 106 & -- \\
\hline 7 & \multicolumn{3}{|c|}{ Overall Prevalence Rate } & 27.89 \\
\hline
\end{tabular}

Sensitivity/resistant pattern of bacterial pathogens isolated from well water samples

Sensitivity/Resistant percentage of various classes of antibiotics against Escherichia coli was assessed and recorded in Table 4. Four classes of 8 antibiotics were used against 35 isolates of E. coli. Four classes of 8 antibiotics were used against 35 isolates of E. coli. Among that Quinolones derivative i.e., Sparfloxacin showed 100\% sensitivity followed by Carbapenems i.e., Imipenem $94.2 \%$ and Meropenem $85.6 \%$ sensitivity showed respectively. All isolates of $E$. coli, mild to moderate sensitivity against Norfloxacin (57.1\%), Nalidixic Acid (48.5\%), Nitrofurontoin (38.5\%) and Ertapenem, Aztreonam (31.4\%) respectively. The result revealed that Sparfloxacin and Meropenem antibiotics were best drug of choice against these isolates. The resistant nature of $E$. coli also rapidly increased when these bacterial isolates present in the not only clinical line and environmental condition also influence the resistant level. A few strains were fallen in intermediate result (Buffer zone) and these strains retested and the same results were documented.

Table 4: Sensitivity/Resistant pattern of various classes of antibiotics against Escherichia coli

\begin{tabular}{|c|c|c|c|c|}
\hline \multirow{2}{*}{$\begin{array}{l}\text { Antibacterial agents and its strength } \\
\qquad(\mu \mathrm{g})\end{array}$} & \multirow[b]{2}{*}{ Symbol } & \multicolumn{3}{|c|}{ Escherichia coli $-(n=35)$} \\
\hline & & S (\%) & I (\%) & R (\%) \\
\hline \multicolumn{5}{|c|}{ Carbapenems } \\
\hline Imipenem $(10 \mu \mathrm{g})$ & IMP & $33(94.2)$ & $2(4.8)$ & -- \\
\hline Meropenem $(10 \mu \mathrm{g})$ & MRP & $30(85.7)$ & -- & $05(14.3)$ \\
\hline Ertapenem $(10 \mu \mathrm{g})$ & ETP & $24(68.6)$ & -- & $11(31.4)$ \\
\hline \multicolumn{5}{|c|}{ Monobactams } \\
\hline Aztreonam $(30 \mu \mathrm{g})$ & AT & $23((65.7)$ & $01(2.9)$ & $11(31.4)$ \\
\hline \multicolumn{5}{|c|}{ Quinolones } \\
\hline Nalidixic Acid $(30 \mu g)$ & NA & $18(51.5)$ & -- & $17(48.5)$ \\
\hline Sparfloxacin $(5 \mu \mathrm{g})$ & SPX & $35(100)$ & -- & -- \\
\hline Norfloxacin $(10 \mu \mathrm{g})$ & NX & $15(42.9)$ & -- & $20(57.1)$ \\
\hline \multicolumn{5}{|c|}{ Nitrofuran } \\
\hline Nitrofurontoin $(300 \mu \mathrm{g})$ & NIT & $22(62.85)$ & -- & $13(38.5)$ \\
\hline
\end{tabular}

(S)- Sensitivity, (I) - Intermediate, (R) - Resistant

Sensitivity/Resistant percentage of various classes of antibiotics against Salmonella spp. was assessed and recorded in Table 5. A total six class of antibiotics (8 antibiotics) were against all isolates of Salmonella, among that (09)100\% sensitivity was documented with Gentamycin (Aminoglycosides class) followed by Co-Trimoxazole (Sulfonamides class) and Meropenem (Carbapenem class) 77.8\% respectively. Tobramycin and Chloramphenicol also moderately inhibited the growth of Salmonella isolates. Nearly five classes of antibiotics were resistant towards Salmonella isolates, such as, Ertapenem, Ofloxacin and Nitrofurontoin (45.5\%) and Tobramycin and Chloramphenicol also showed the resistant. This is due to repeated exposure of these antibiotics and presence of Salmonellae widely in the environment. 
Table 5: Sensitivity/Resistant pattern of various classes of antibiotics against Salmonella spp.

\begin{tabular}{|c|c|c|c|c|}
\hline \multirow{2}{*}{$\begin{array}{l}\text { Antibacterial agents and its strength } \\
\qquad(\mu \mathrm{g})\end{array}$} & \multirow[b]{2}{*}{ Symbol } & \multicolumn{3}{|c|}{ Salmonella spp. - $(\mathrm{n}=09)$} \\
\hline & & S (\%) & I (\%) & R (\%) \\
\hline \multicolumn{5}{|c|}{ Carbapenems } \\
\hline Meropenem $(10 \mu \mathrm{g})$ & MRP & $07(77.8)$ & -- & $02(22.2)$ \\
\hline Ertapenem $(10 \mu \mathrm{g})$ & ETP & $05(55.5)$ & -- & $04(45.5)$ \\
\hline \multicolumn{5}{|c|}{ Quinolones } \\
\hline Ofloxacin $(5 \mu \mathrm{g})$ & OF & $05(55.5)$ & -- & $04(45.5)$ \\
\hline \multicolumn{5}{|c|}{ Sulfonamides } \\
\hline Co-trimoxazole $(125 \mu \mathrm{g})$ & COT & $07(77.8)$ & -- & $02(22.2)$ \\
\hline \multicolumn{5}{|c|}{ Lincosamides } \\
\hline Chloramphenicol $(30 \mu \mathrm{g})$ & $\mathrm{C}$ & $06(66.6)$ & -- & $03(33.4)$ \\
\hline \multicolumn{5}{|c|}{ Aminoglycosides } \\
\hline Tobramycin $(10 \mu \mathrm{g})$ & TOB & $06(66.6)$ & -- & $03(33.4)$ \\
\hline Gentamycin $(10 \mu \mathrm{g})$ & GEN & $09(100)$ & -- & -- \\
\hline \multicolumn{5}{|c|}{ Nitrofuran } \\
\hline Nitrofurontoin $(300 \mu \mathrm{g})$ & NIT & $05(55.5)$ & -- & $04(45.5)$ \\
\hline
\end{tabular}

(S)- Sensitivity, (I) - Intermediate, (R) - Resistant

Sensitivity/Resistant percentage of various classes of antibiotics against Shigella spp. was assessed and recorded in Table 6. Six classes of antibiotics were admitted against all 33 isolates of Shigella, among that none of the class of antibiotic showed $100 \%$ sensitivity rather than Nitrofurontoin showed (75.8\%), Meropenem (69.7\%) and Piperacillin, Gentamycin (60.6\%) were documented respectively. Utmost five classes of antibiotics, Co-
Trimoxazole 18(55.6), Ofloxacin and Tobramycin 18(51.6), Ertapenem 14(42.4) and Gentamycin 13(39.4) were resistant against isolates of Shigella. The result revealed that some occasion cross resistance between humans and environment also plays a major role in developing resistance in microorganisms. Intermediate results were also reconfirmed by retest.

Table 6: Sensitivity/Resistant pattern of various classes of antibiotics against Shigella spp.

\begin{tabular}{|c|c|c|c|c|}
\hline \multirow{2}{*}{$\begin{array}{l}\text { Antibacterial agents and its strength } \\
\qquad(\mu \mathrm{g})\end{array}$} & \multirow[b]{2}{*}{ Symbol } & \multicolumn{3}{|c|}{ Shigella spp. - $(\mathrm{n}=33)$} \\
\hline & & $S(\%)$ & I (\%) & R (\%) \\
\hline \multicolumn{5}{|c|}{ Carbapenems } \\
\hline Meropenem $(10 \mu \mathrm{g})$ & MRP & $23(69.7)$ & -- & $10(31.3)$ \\
\hline Ertapenem $(10 \mu \mathrm{g})$ & ETP & $19(57.6)$ & -- & $14(42.4)$ \\
\hline \multicolumn{5}{|c|}{ Quinolones } \\
\hline Ofloxacin $(5 \mu \mathrm{g})$ & $\mathrm{OF}$ & $14(42.4)$ & $02(6.0)$ & $17(51.6)$ \\
\hline \multicolumn{5}{|c|}{ Sulfonamides } \\
\hline Co-trimoxazole $(125 \mu \mathrm{g})$ & COT & $15(45.4)$ & -- & $18(55.6)$ \\
\hline \multicolumn{5}{|c|}{ B-Lactam Antibiotic/Aminopenicillins } \\
\hline Piperacillin $(30 \mu \mathrm{g})$ & PI & $20(60.6)$ & $03(9.1)$ & $10(30.3)$ \\
\hline \multicolumn{5}{|c|}{ Aminoglycosides } \\
\hline Tobramycin $(10 \mu \mathrm{g})$ & TOB & $16(48.4)$ & -- & $17(51.6)$ \\
\hline Gentamycin $(10 \mu \mathrm{g})$ & GEN & $20(60.6)$ & -- & $13(39.4)$ \\
\hline \multicolumn{5}{|c|}{ Nitrofuran } \\
\hline Nitrofurontoin $(300 \mu \mathrm{g})$ & NIT & $25(75.8)$ & -- & $08(24.2)$ \\
\hline
\end{tabular}

(S)-Sensitivity, (I) - Intermediate, (R) - Resistant 
Sensitivity/Resistant percentage of various classes of antibiotics against Proteus spp. was assessed and recorded in Table 7. Six classes of antibiotics were implemented against 17 isolates of Proteus spp. among that Aminoglycosides class (Tobramycin - 100\% and Gentamycin - 70.6\%), Nitrofuran (Nitrofurontoin - 88.2\%) and Sulfonamides (Co-Trimoxazole

$-76.5 \%$ ) sensitivity observed. It was interestingly noted that among five various isolates of present research, Proteus spp. was documented maximum level of resistance, such as, Norfloxacin (88.2\%), Ertapenem (76.5\%), Meropenem $(70.6 \%)$ and Piperacillin (52.9\%). This result revealed that how a few classes of antibiotics how actively involved in inhibition equally a few antibiotics were undergoing resistance.

Table 7: Sensitivity/Resistant pattern of various classes of antibiotics against Proteus spp.

\begin{tabular}{|c|c|c|c|c|}
\hline \multirow{2}{*}{$\begin{array}{l}\text { Antibacterial agents and its strength } \\
\qquad(\mu \mathrm{g})\end{array}$} & \multirow[b]{2}{*}{ Symbol } & \multicolumn{3}{|c|}{ Proteus spp. - $(\mathrm{n}=17)$} \\
\hline & & $S(\%)$ & I (\%) & R (\%) \\
\hline \multicolumn{5}{|c|}{ Carbapenems } \\
\hline Meropenem $(10 \mu \mathrm{g})$ & MRP & $05(29.4)$ & -- & $12(70.6)$ \\
\hline Ertapenem $(10 \mu \mathrm{g})$ & ETP & $04(23.5)$ & -- & $13(76.5)$ \\
\hline \multicolumn{5}{|c|}{ Quinolones } \\
\hline Norfloxacin $(10 \mu \mathrm{g})$ & NX & $02(11.8)$ & -- & $15(88.2)$ \\
\hline \multicolumn{5}{|c|}{ Sulfonamides } \\
\hline Co-Trimoxazole $(125 \mu \mathrm{g})$ & COT & $13(76.5)$ & -- & $04(23.5)$ \\
\hline \multicolumn{5}{|c|}{ B-Lactam Antibiotic/Aminopenicillins } \\
\hline Piperacillin $(30 \mu \mathrm{g})$ & PI & $08(47.1)$ & -- & $09(52.9)$ \\
\hline \multicolumn{5}{|c|}{ Aminoglycosides } \\
\hline Tobramycin $(10 \mu \mathrm{g})$ & TOB & $17(100)$ & -- & -- \\
\hline Gentamycin $(10 \mu \mathrm{g})$ & GEN & $12(70.6)$ & -- & $05(29.5)$ \\
\hline \multicolumn{5}{|c|}{ Nitrofuran } \\
\hline Nitrofurontoin $(300 \mu \mathrm{g})$ & NIT & $15(88.2)$ & $02(11.8)$ & -- \\
\hline
\end{tabular}

(S)- Sensitivity, (I) - Intermediate, (R) - Resistant

A few strains were fallen in intermediate result (Buffer zone) and these strains again tested and the same results were documented.

Sensitivity/Resistant percentage of various classes of antibiotics against Enteroccoccus spp. was assessed and recorded in table 8. Eight classes of antibiotics were used against 12 isolates of Enterococcus spp., among that $83.3 \%$ sensitivity recorded with Ampicillin, Norfloxacin, 75\% were observed with Co-Trimoxazole and Gentamycin, $66.6 \%$ were documented with Vancomycin respectively. Three classes of antibiotics were showed the resistant level, viz., 50\% resistant (Nitrofurontoin), 41.7\% resistant with (Kanamycin and Imipenem) and $33.3 \%$ (Vancomycin). Normally Enterococcus spp. is environmental contaminant that to different water sources and this organism also one of the reasons for water indicator. The presence of Enterococcus spp. in water system also indication of other organisms like faecal coliforms and others.

Table 8: Sensitivity/Resistant pattern of various classes of antibiotics against Enterococcus spp.

\begin{tabular}{|c|c|c|c|c|}
\hline \multirow{2}{*}{$\begin{array}{l}\text { Antibacterial agents and its strength } \\
\qquad(\mu \mathrm{g})\end{array}$} & \multirow[b]{2}{*}{ Symbol } & \multicolumn{3}{|c|}{ Enterococcus spp. - $(\mathrm{n}=12)$} \\
\hline & & S (\%) & I (\%) & R (\%) \\
\hline \multicolumn{5}{|c|}{ Aminoglycosides } \\
\hline Kanamycin $(30 \mu \mathrm{g})$ & K & $07(58.3)$ & -- & $05(41.7)$ \\
\hline \multicolumn{5}{|c|}{ Carbapenems } \\
\hline Imipenem $(10 \mu \mathrm{g})$ & IPM & $07(58.3)$ & -- & $05(41.7)$ \\
\hline \multicolumn{5}{|c|}{ B-Lactam Antibiotic } \\
\hline Ampicillin $(10 \mu \mathrm{g})$ & AMP & $10(83.3)$ & -- & $02(16.7)$ \\
\hline \multicolumn{5}{|c|}{ Quinolones } \\
\hline Norfloxacin $(5 \mu \mathrm{g})$ & NX & $10(83.3)$ & -- & $02(16.7)$ \\
\hline \multicolumn{5}{|c|}{ Sulfonamides } \\
\hline Co-Trimoxazole $(125 \mu \mathrm{g})$ & COT & 09(75) & -- & $03(25)$ \\
\hline \multicolumn{5}{|c|}{ Aminoglycosides } \\
\hline Gentamycin $(10 \mu \mathrm{g})$ & GEN & 09(75) & -- & $03(25)$ \\
\hline \multicolumn{5}{|c|}{ Glycopeptide } \\
\hline Vancomycin (5) & VA & $08(66.6)$ & -- & $04(33.4)$ \\
\hline \multicolumn{5}{|c|}{ Nitrofuran } \\
\hline Nitrofurontoin $(300 \mu \mathrm{g})$ & NIT & $06(50)$ & -- & $06(50)$ \\
\hline
\end{tabular}

(S)- Sensitivity, (I) - Intermediate, (R) - Resistant 
Prevalence of MDR bacterial isolates among water samples listed in table 9. Based on the sensitivity/resistant result, bacterial isolates are resistant with three and more classes of antibiotic were considered as multi drug resistant (MDR) isolate. Out of 35 E. coli, 13 isolates were identified as MDR and four classes of antibiotics were resistant with these isolates, out of 9 Salmonella isolates, 4 were recorded as
MDR and five classes of antibiotics included, out of 33 Shigella isolates, 21 isolates were documented as a MDR and it resistant with five classes of antibiotics, of the 17 isolates of Proteus isolates, 9 were observed as MDR and these isolates resistant with five classes of antibiotics and out of 12 Enterococcus spp., 4 isolates of Enterococcus spp., and maximum of resistant with six classes of antibiotics.

Table 9: Prevalence of Multi Drug Resistance (MDR) bacterial pathogens

\begin{tabular}{|l|l|l|l|}
\hline S.No. & Bacterial isolate & MDR Isolates & Classes of Antibiotics \\
\hline 1 & Escherichia coli $(\mathrm{n}=35)$ & 13 & Carbapenems, Nitrofuran, Quinolones and Monobactams \\
\hline 2 & Salmonella spp. (n=09) & 03 & $\begin{array}{l}\text { Carbapenems, Quinolones, Nitrofuran, Lincosamides and } \\
\text { Aminoglycosides }\end{array}$ \\
\hline 3 & Shigella spp. (n=33) & 21 & $\begin{array}{l}\text { Carbapenems, Quinolones, Sulfonamides, B-Lactam } \\
\text { Antibiotic/Aminopenicillins and Nitrofuran }\end{array}$ \\
\hline 4 & Protues spp. (n=17) & 09 & $\begin{array}{l}\text { Carbapenems, Quinolones, Sulfonamides, B-Lactam } \\
\text { Antibiotic/Aminopenicillins And Aminoglycosides }\end{array}$ \\
\hline 5 & Enterococcus spp. (n=12) & 04 & $\begin{array}{l}\text { Aminoglycosides, Carbapenems, B-Lactams, Quinolones, } \\
\text { Sulfonamides, Glycopeptide and Nitrofuran }\end{array}$ \\
\hline
\end{tabular}

\section{DISCUSSION}

Bacteriological analysis of water is used to assess its quality for human consumption, domestic use to safe guard public health. Majority of the water sources harboured enter pathogens and were also reported to be of poor microbiological quality and unsafe for consumption. ${ }^{19}$ The presence of enteric bacterial pathogens in water sources may spell health hazards such as diarrhoea diseases, which accounts for a substantial degree of morbidity and mortality in adults and children. ${ }^{20}$ Management of diarrhoea may require the administration of antibiotics. However, several bacteria are known to be resistant to a wide array of antibiotics. Drinking water is not a natural environment for coliform bacteria, their percent indicates microbial water deterioration. ${ }^{21}$

Out of 380 samples screened 106 samples were culture positive $106(27.89 \%)$. Among the culture positives, five predominant genera were isolated, such as, Escherichia coli 35(9.2\%), Salmonella spp. 09(2.3\%) Shigella spp. 33(8.68\%), Proteus spp. 17(4.47\%), and Enterococcus spp. 12(3.15\%). Eliku and Suleiman 22 conducted a study in Adama, Ethiopia and they reported high prevalence then the present study specifically E. coli. A study conducted in drinking water sources in South Africa and Zimbabwe by Gundry, ${ }^{23}$ revealed that $12 \%$ of samples were contaminated with $E$. coli, which was nearly similar to $9.2 \%$ prevalence were isolates of $E$. coli in well water in this study. The present sensitivity/resistant study results revealed that Sparfloxacin and Meropenem antibiotics were best choice against these isolates. The resistant nature of $E$. coli also rapidly increased when these bacterial isolates present in the not only clinical and environmental condition also influence the resistant level. In this study, $9.2 \%$ of $E$. coli isolates were resistant to four classes of antibiotics. Bello et al. ${ }^{24}$ in Nigeria, reported high level of MDR strains among $E$. coli in well water samples.

Similarly, A study was done on river and fountain water and a total of 201 bacterial isolates were identified in South Africa. E. coli (40) was the predominant bacteria followed by Salmonella (30), Shigella (30) Campylobacter (26) and Aeromonas, Enterobacter, and Plesiomonas shigelloides each accounted $20 \% .25$ Salmonella spp. is a recognized human pathogen and its waterborne transmission has been well documented. ${ }^{26}$ In the present study total of 9 isolates of Salmonella spp. and 33 isolates of Shigella spp. were isolated from the 380 well water samples. Similar to the present study, 6 samples gave positive with Salmonella spp. from sixty-eight samples of Argüello Lagoon in the city of Resistencia. ${ }^{27}$ Six classes of antibiotics were admitted against all Salmonella spp. and Shigella spp. Among that none of the classes of antibiotic showed 100 sensitivity rather than Nitrofurontoin showed (75.8\%), Meropenem (69.7\%) and Piperacillin, Gentamycin (60.6) were documented respectively against Salmonella. Ultmost five classes of antibiotics, Co-Trimoxazole 18(55.5\%), Ofloxacin and Tobramycin 18(51.6\%), Ertapenenem 14(42.4\%) and Gentamycin 13(39.4\%) were resistant against the isolates of Shigella. Similar to the present study results, so many ram negative bacterial isolates such as Escherichia coli $(22.7 \%)$, Enterobacter aerogenes (2.5\%), Salmonella spp. (13.3\%), Shigella spp. (19.3\%), Proteus spp. (18.5\%), Klebsiella spp. $(19.3 \%)$ and Pseudomonas aeruginosa (4.2\%). ver $10 \%$ of the bacteria were resistant to four or more antibiotic. Antibiotic resistance was highest in members of the genera Enterobacter, Pseudomonas, and Proteus. ${ }^{28}$

In the present study, 17(4.47\%) Proteus spp. prevalence was recorded, six classes of antibiotics were implemented against 17 isolates of Proteus spp. among that Aminoglycosides class (Tobramycin - 100\% and Gentamycin - 70.6\%), Nitrofuran (Nitrofurontoin - 88.2\%) and Sulfonamides (Co-Trimoxazole - 76.5\%) sensitivity observed. It was interestingly noted that among five various isolates of present research Proteus spp. was documented maximum level of resistance, such as, Norfloxacin (88.2\%), Ertapenem (76.5\%), Meropenem (70.6\%) and Piperacillin $(52.9 \%)$. These results agree with a similar study by Ash et al. ${ }^{29}$ who demonstrated over $40 \%$ of the encountered bacteria isolates from freshwater samples from 16 U.S. rivers were resistant to more than one antibiotic. In a similar vein, among the most common resistant organisms encountered in the study belonged to the genus Enterobacter. A similar study by Ajayi and Akonai ${ }^{30}$ also demonstrated multiple antibiotic resistance among microorganisms encountered in water samples from available sources. 
In this study out of 106 12(3.15) Enterococcus spp. were isolated different well water samples and tested against various classes of antibiotics. Eight classes of antibiotics were used against 12 isolates of Enterococcus spp. Among that 83.3 sensitivity recorded with Ampicillin, Norfloxacin, $75 \%$ were observed with Co-Trimoxazole and Gentmycin, $66.6 \%$ were documented with Vancomycin respectively. Three classes of antibiotics were showed the resistant level, viz., 50\% resistant (Nitrofuontion), $41.7 \%$ resistant with (Kanamycin and Imipenem) and 33.3\% (Vancomycin). Normally Enterococcus spp is environmental contaminant that to different water sources such as spring, well and tap and this organism also one of the reasons for water indicator. The presence of Enterococcus spp. in water system also indicated of other organisms like faecal coliforms and others. Several studies have revealed that ground water contamination by faecal pathogens generally occur through surface run-off, leaching and direct faecal deposition into water bodies via several livestock production activities like confined animal feedlot, free range system and land spreading of manure. ${ }^{31}$

In this present study, 21 isolates of Shigella spp. showed multidrug resistant (MDR) out of 33 isolates and 13 isolates of $E$. coli out of 35 isolates showed multidrug resistant. Similarly, multidrug resistance is common in bacteria that cause diarrheal diseases. Isolation from water sources in these rural communities of antibiotic resistant pathogenic bacteria such as Salmonella, Escherichia coli and Shigella is thus a primary concern. These organisms are mostly responsible for several gastrointestinal illness linked to contamination of drinking water. 32,33 The present study results clearly showed that underground water sources which serve as drinking water to rural communities could also serve as reservoirs for pathogens resistant against number of antibiotics. Unfortunately, the lack of affordable treatment facilities in most rural settings rule out the possibilities of microbial reduction before use of such waters for drinking and other domestic purposes. The incidence of antibiotic-resistant enteric pathogens in rural water supply thus constitutes potential health hazards to rural dwellers. Among the resistant enteric pathogens encountered in this study were E. coli, Salmonella spp., Shigella spp. Enterococcus spp. and Proteus spp. This finding is in agreement with the work of Akinyemi et al. ${ }^{34}$ that highlighted Enterobacter aerogenes, Proteus, E. coli, Salmonella and Shigella as among the enteric pathogens commonly isolated from well waters and other open sources.

\section{CONCLUSION}

This study has shown that there is a high possibility of bacterial pathogens such as Escherichia coli, Salmonella spp., Shigella spp., Proteus spp. and Enterococcus spp. in the well water samples of Wolaita Sodo. Presence of these organisms indicates the water samples consist of coliforms as well as some of the pathogenic organisms and it leads to waterborne diseases. Therefore, to reduce the high incidence of well water contamination, it is advocated that wells dug must be deep, far away from latrines and covered adequately. Based on the antimicrobial susceptibility test results, presence of multiple drug resistance bacterial pathogens in the well water samples collected from Wolaita Sodo proposed that there has been an indiscriminate usage of antibiotics tested. The high prevalence rate of multiple drug resistant bacterial pathogens in the well water samples could potentially pose a threat to people consuming this water. Therefore, the present study suggesting to monitor the quality of water and strict quality control measures should be put in place to ensure the effective treatment of drinking water.

\section{CONFLICT OF INTEREST: None}

\section{REFERENCES}

1. Ash bolt NJ. Microbial contamination of drinking water and disease outcomes in Developing Regions. Toxicology, 2004; 198 (1-3):229-238.

2. Gerald P. Water Science. University of Washington. Available from http;//faculty.washigton.edu/ghp/researcthemes/watersciences.Accessedon; Nov, 015.

3. WHO/UNICEF. Progress on drinking water and sanitation; 2014 updates. New York, NY USA and Geneva, Switzerland, 2014.

4. Suthar S, Chhimpa V, Singh S. Bacterial contamination in drinking water; a case study in rural areas of northern Rajasthan, Indian, Monitor. Assess., 2009; 159:43-50.

5. World Health Organization (WHO). Guidelines for drinking water.4th Edition Geneva; WHO Press, 2011b.

6. JMP (Joint Monitoring Program me). Joint Monitoring Program me by WHO and UNICEF for Water Supply report, Geneva Switzerland, 2008.

7. WHO, Guidelines for Drinking Water Quality, vol. 1, World Health Organization, Geneva, Switzerland, 3rd edition, 2004.

8. Mpenyana-Monyatsi L, Onyango MS, Momba MNB. Groundwater quality in South African Rural Community: A Possible Threat to Public Health. Pol. J. Environ. Stud., 2012; 21(5):1349-1358.

9. Astal Z. Bacterial pathogens and their antimicrobial Susceptibility in Gaza Strip, Palestine. Pak J Med Sci., 2004; 20:365-70.

10. Seas C, Alarcon M, Aragon JC, Beneit S, Quiñonez M, Guerra H Gotuzzo E. Surveillance of Bacterial Pathogens Associated with Acute Diarrhea in Lima, Peru. Int. J. Infect. Dis., 2000; 4:96-99.

11. Medema GJ, Payment P, Dufour A, Robertson W, Waite M, Hunter P, Kirby R, Anderson Y. Safe drinking water: an ongoing challenge. In Assessing Microbial Safety of Drinking Water. Improving Approaches and Method; WHO \& OECD, IWA Publishing: London, UK, 2003; 11-45.

12. Beyene A, Hailu T, Faris K, Klos H. Current status and trends of access to sanitation in Ethiopia and the need to raise indicators to monitor progress in the post -2015 era. BMC Public Health., 2015; 15:541.

13. Sayah RS, Kaneene JB, Johnson Y, Miller R. Patterns of antimicrobial resistance observed in Escherichia coli isolates obtained from domestic- and wild-animal fecal samples, human septage, and surface water. Appl Environ Microbiol., 2005; 71:1394-1404. 10.1128/AEM.71.3.1394-1404.2005.

14. Thrusfield M. Veterinary Epidemiology. 3rd ed. UK: Black well science ltd., 2007; p233.

15. Dubey RC, Maheswari DK. Practical microbiology First edition, S Chand and Company Ltd., New Delhi, 2004.

16. Chessbrough M. District laboratory practice in tropical countries, part-2, New York, USA: Cambridge university, 2006; 184-186.

17. Bauer AW, Kirby MM, Sherris JC, Truck M. Antibiotic susceptibility testing by a standardized single disk method. $\mathrm{Am}$ J Clin. Pathol., 1966; 45:493-6.

18. Fennel J, Vellinga A, Hanahoe B, Morris D, Boyle F, Higgins F, Lyins M, Connell K, Keudy D, and Cormican M. Increasing prevalence of ESBL production among Irish clinical Enterobacteriaceae from 2004 to 2008: An observational study. BMC Infectious Diseases, 2012; 12:116.

19. Kemmerer K. Resistance in the environment. I Antimicrob Chemother., 2004; 54:311- 320.

20. Black RE. Persistent diarrhea in children in developing countries. Pediatr. Infect. Dis. J. 1993; 12:751-761.

21. Rompre A, Servais P, Baudart J, De-Robin M, Laurent P. Detection and enumeration of coli. Forms in drinking water sources, current methods and emerging approaches. J.Micrbiol Met., 2002; 49:31-45

22. Eliku T, Sulaimn H. Assessment of physical-chemical bacteriological quality of drinking water sources and house hold in Adama Town,Oromiya Regional State,Ethiopia. Afr,J,Enviromental Si,Technol., 2015; 9:413-419.

23. Gundry W. Stephen. Contamination of drinking water between sources and point of use in rural households of South Africa and Zimbabwe; application for monitoring the Millennium development Goals for water. Water and Environmental management research center, University of Bristol, 83 Wood land road, Bristol Bs81 US, UK, 2006. 
24. Bello B, Adebolu, Oyetayo V. Antibiogram and plasmid profile of Escherichia coli isolates in well water in Akure, South Western Nigeria. J. pharm., 2013; 3(7):30-37.

25. Dahunsi SO, Owamah HI, Ayandiran TA, Oranusi US. Drinking water quality and public health of selected communities in South Western Nigeria. Water Qual. Exp. Health, 2014; 6:143153.

26. Cabral JPS. Water microbiology. Bacterial pathogens and water. International Journal of Environmental Research and Public Health, 2010; 7(10):3657-703. http://dx.doi.org/10.3390\%2Fijerph7103657.

27. María Fernanda Tracogna, Liliana Silvina Lösch, José Mario Alonso, Luis Antonio Merino. Detection and characterization of Salmonella spp. in recreational aquatic environments in the Northeast of Argentina. Revista Ambiente \& Água - An Interdisciplinary Journal of Applied Science, 2013; 8(2):18-26.

28. Oluyege JO, Dada AC, Odeyemi AT. Incidence of multiple antibiotic resistant Gram-negative bacteria isolated from surface and underground water sources in south western region of Nigeria. Water Science \& Technology, 2009; 59(10):19291936.
29. Ash RJ, Mauck B, Morgan M. Antibiotic resistance of Gramnegative bacteria in rivers, United States. Emerg. Infect. Dis., 2002; 8:713-716.

30. Ajayi AO, Akonai KA. Antibiotic profile of microorganisms encountered in the Lagos Lagoon. Afr. J. Biomed. Res., 2003; 6:79-84.

31. Ahmed W, Neller R, Katouli M. Host species specific metabolic fingerprint database for Enterococci and Escherichia coli and its application to identify source of faecal contamination in surface waters. Applied Environmental Microbiology, 2005; 71(8):4461-4468.

32. Alamanos Y, Maipa V, Levidiotou S, Gessouli E. A community waterborne outbreak of gastroenteritis attributed to Shigella sonnei. Epidemiol. Infect., 2000; 125:499-503.

33. Chen KT, Chen CJ, Chiu JP. A school waterborne outbreak involving both Shigella sonnei and Entamoeba hystolytical. J. Environ. Health, 2001; 64:9-13.

34. Akinyemi KO, Oyefolu AOB, Salu OB, Adewale OA, Fasure AK. Bacterial pathogens associated with tap and well waters in lagos, Nigeria. East Cent. Afr. J. Surg., 2006; 11(1):110-117. 